\title{
Association of Vitamin Profile with Oxidant / Antioxidant Status in Iraqi B -Thalassemic Major Children
}

\author{
Hasan F Al-Azzawie* and Noor A salman \\ Department of biotechnology, College of science, Baghdad University, Iraq
}

Submission: November 28, 2017; Published: December 11, 2017

*Corresponding author: Hasan F Al-Azzawie, Department of biotechnology, College of science, Baghdad University, Iraq, Email: hazzawie2@yahoo.com

\begin{abstract}
Objective: The aim of the study was to examine the association of blood vitamin profile with oxidant/antioxidant status in Iraqi children with $\beta$-Thalassemic

Material and Method: Samples from 75 children with $\beta$-Thalassemic major and 50 healthy controls were used. All children were under 13 years of age and they were receiving regular chelation therapy. Lipid per oxidation marker, malondialdehyde, glutathione(GSH), Catalase(Cat), glutathioneperoxidase(GPx), Paraoxonase(PON1) Lipid profile, apoliprotein a and B-100, Hydroxy gunanosine and Isoprostane f2, ferritin and serum iron, vitamin A,C,E and D were enrolled and examined in the study.

Result: Mean serum malondialdehyde(MDA) levels were significantally elevated $(\mathrm{p}<0.001)$ in $\beta$-thalassemic children in comparison with controls together with compensatory decrease in Paraoxonase (PON1), glutathione peroxidase(GPx) and catalase (CAT) activity in addition reduced glutathione (GSH), Vitamin E,C,A and D were detected. Cholesterol, HDL-cholesterol, LDL-cholesterol levels were found to be significantly lower $(p<0.05)$, while the triglyceride level was found to be significantly higher $(p<0.05)$ in patients with $\beta$-Thalassemic major than in the controls, in addition negative correlation between serum ferritin levels and all vitamin profile levels , confirming hypovitaminism status and antioxidant depletion due to iron overload. While serum ferritin levels showed a positive correlation with elevated MDA suggesting that iron overload is involved in the oxidative stress status shown in cells.
\end{abstract}

Conclusion: Reduction of antioxidant levels in Iraqi $\beta$ major thalassemic children put them at higher risk for cardiovascular complications. So administration of selective antioxidant along with multivitamin elements and minerals were necessary to reduce the extent of oxidative damage and related complications in $\beta$-Thalassemic major and this need further evaluation.

Keywords: $\beta$-Thalassemic major; Vitamin profile; Oxidant; Antioxidant; Ferritin

\section{Introduction}

Thalassemic are a group of hereditary anemia which happen as a result of genetic disorders that affect the synthesis of normal hemoglobin $(\mathrm{Hb})$, in which a reduced rate of synthesis of one or more of the globin chains leads to defective Hb production, and damage to the red cells or their precursors [1]. $\beta$-Thalassemic is more common in Mediterranean countries and islands including Cyprus, Sardinia, and Malta [2]. However both $\alpha$ and $\beta$ Thalassemic types are common in Africans and Black Americans [3]. Thalassemic is usually associated with many complications such as hepatosplenomegaly, arthrosclerosis infections, gall stones and bone deformities that alter facial features and result in pathogenic fractures [4]. Studies on $\beta$-thalassemic patients suggest that they may develop symptoms of iron loading that includes chelating therapy complications, heart and liver diseases, and endocrinopathies [5]. Normally, erythrocytes degrade reactive oxygen species (ROS) via the actions of superoxide dismutase (SOD), catalase (CAT) and glutathione peroxidase (GPx). In $\beta$-Thalassemic major, intra erythrocyte release of heme induces a glutathione (GSH)-dependent selfamplifying and self propagating $\mathrm{Hb}$ oxidation pathway, resulting in injury to the thalassemic cell [6]. In addition, iron can serve as a potent catalyst of lipid peroxidation [7]. The presence of hypochromia may facilitate oxidation of the red cell membrane by reducing the amount of $\mathrm{Hb}$ available for buffering protection [8].

The peripheral red cells of patients with $\beta$-Thalassemic demonstrate a variety of morphological, biochemical and metabolic changes, which specifically contribute to the extent and severity of lipid per oxidation and hemolysis [9]. Unpaired $\alpha-\mathrm{Hb}$ chains may denature and bind to the cell membrane, thus giving rise to cytoskeleton alterations and lipid peroxidation [10]. The free $\alpha$ chain in $\beta$-Thalassemic increase autoxidation rates by about two times faster than normal $\mathrm{Hb} \mathrm{A} 7$. It has been reported that the accumulation and autoxidation of the unpaired 
$\alpha$-globin chains in severe $\beta$-Thalassemic would generate ROS; superoxide (02-) and hydrogen peroxide that would cause accelerated apoptosis and ineffective erythropoiesis [11]. Therefore, we hypothesize that oxidative stress is a major factor of morbidity in Iraqi $\beta$-thalassemic children and is correlated with iron overload and metabolic dysfunctions. In order to verify this hypothesis we evaluated vitamin profile and its correlation with ferritin levels and oxidant/antioxidant parameters in Thalassemic patients receiving repeated blood transfusions and on regular chelation therapy at the time of study compared with normal controls.

\section{Materials and Methods}

The current study involved $75 \beta$-thalassemic major patients aged 3-15 years (45 males and 30 females) admitted to Hematology Department, Pediatric Ibn Albalday Hospital, A group of 50 children in the same age and sex and free from , chronic diseases, malnutrition, chronic diseases and smoking or any cause of oxidative stress were taken as healthy controls. The beta thalassemic major patients received blood transfusion regularly with regular chelation therapy at the time of study. $\beta$ - Thalassemia major patients were previously diagnosed by ultimately molecular characterization of $\beta$-Thalassemia, hemolytic state assessment, complete blood picture (CBC) analysis and hemoglobin electrophoresis. Venous blood samples $(5 \mathrm{ml})$ were collected from $\beta$-thalassemic major patients and normal children in the same age and sex, withdrawn into two separate tubes: one EDTA and one plain tubes and collected under complete aseptic conditions from all children under investigation. The EDTA whole blood sample tube was used for hemoglobin determination, complete blood picture, hematocrit, the whole blood in plain tube was centrifuged for 10 minutes at $3000 \mathrm{rpm}$ and the sera were separated and used for biochemical parameters. Serum MDA concentration was determined by using the method described by Draper and Hadley based on TBA reactivity $[11,12]$. GSH was determined with a colorimetric assay according to the method of Beutler [13]. The activity of GPx was measured with a commercially available kit (Ransel glutathione peroxidase, Randox Laboratories) in erythrocytes at $340 \mathrm{~nm}$ by measuring the decrease of NADPH absorbance. This method is based on that of Paglia and Valentine [14]. Catalase (CAT) activity was determined using de Aebi [15]. Serum biomarkers 15-isoprostane F2t (F2-Iso) and 8-Hydroxydeoxyguanosine (8-OHdG) were determined using ELISA assay kits (Oxford Biomedical Research). The estimation of paraoxonase1 activity was done according to the method of Menys method [16]. Cholesterol was determined by the enzymatic method as described by Thomas [17]. High density lipoprotein-cholesterol (HDL-C) and Low density lipoprotein-cholesterol (LDL-C) were determined according to method described by Gordon [18]. Triglycerides were determined by the method of Schettler [19]. Apolipoprotein a and B-100 by ELISA kits. Serum level of ferritin was assessed using the ELISA technique from Alpha Diagnostic International Company according to the method of Theurl [20].
For serum iron estimations, Ramsay's Dipyridyl method was used [21].

\section{Results}

Table 1 shows the general characteristics of the study groups about $73 \%$ of the $\beta$-Thalassemia major children parents are 1st degree cousins compared to the control group where the percentage is about $5.0 \%$. Also the percentage of the 2nd degree consanguineous marriages in the patient groups is significantly higher than that of the control group, 13.75 and 7.5 $\%$ respectively. No significant difference in the mean age of the patients $(9.2 \pm 1.3$ years) and the controls ( $8.9 \pm 1.8$ years) of the present work, with male: female ratio of 2:1. A remarkable and a significant difference was reported in the parents' consanguinity of the two groups $(\mathrm{P}<0.001)$. The majority $(62.0 \%)$ of the patients are receiving blood transfusion each $2-3$ weeks and $32.5 \%$ each $4-5$ weeks. The presence of other thalassemic patients within the same family brothers or sisters is obvious and $60.0 \%$ of the current patients have other thalassemic brother and /or sisters which were excluded for biasness issues. Regarding iron chelation, nearly half of the patients withdraw the overloaded iron through the subcutaneous pumps (Deferral pumps), $35 \%$ through intramuscular infusion, while $10 \%$ by intravenous infusion. Oral chelation (X-Jade) of iron is used by $5 \%$ of the patients.

Table 1: General Characteristics of the Study Groups.

\begin{tabular}{|c|c|c|c|}
\hline Parameter & $\begin{array}{l}\text { Patients }(n=75) \\
\text { Mean } \pm \text { sd }\end{array}$ & $\begin{array}{l}\text { Control }(n=75) \\
\text { Mean } \pm \text { sd }\end{array}$ & $P$ value \\
\hline Age & $9.2 \pm 1.3$ years & $8.9 \pm 1.8$ years & ns \\
\hline Sex ( male) & 50 & 52 & $\begin{array}{c}\text { Ch sq test } \\
0.823\end{array}$ \\
\hline Sex (female) & 25 & 22 & $\begin{array}{c}\text { Ch sq test } \\
0.001\end{array}$ \\
\hline \multicolumn{4}{|c|}{ Parents consanguinity } \\
\hline Ist degree & $59(73.75 \%)$ & $2(5 \%)$ & \multirow{3}{*}{$\begin{array}{c}\text { Ch sq test } \\
0.001\end{array}$} \\
\hline 2nd degree & $11(13.75 \%)$ & $3(7.5 \%)$ & \\
\hline Non relatives & $10(12.50 \%$ & $35(87.5 \%)$ & \\
\hline
\end{tabular}

As seen in Table 2 , cholesterol, LDL cholesterol $(\mathrm{p}<0.05)$ and HDL-cholesterol $(p<0.05)$ levels in patients with $\beta$-Thalassemia were found to be significantly lower than those of the control group, while the triglyceride levels were found to be higher $(\mathrm{p}<0.05)$. paraoxonase1, reduced glutathione and catalase levels in patients with $\beta$-thalassemia were found to be significantly lower with significant increased malondialdehyde (MDA) $(\mathrm{p}<0.001)$ level. The biochemical characteristics of the $\beta$-Thalassemic major patients as compared to the controls are presented in table 2. A significant increase was observed in the mean levels of serum MDA $(4.41 \pm 0.52 \mu \mathrm{M}$ vs.1.22 \pm $0.45 \mu \mathrm{M}$ in patients with $\beta$-Thalassemia major as compared to control. Data revealed also that the mean serum ferritin level in patients was markedly higher than that in controls $(1525 \pm$ $29.5 \mathrm{ng} / \mathrm{l}$ vs. $95 \pm 13.8 \mathrm{ng} / \mathrm{ml} \mathrm{p}$-value $<0.0001$ ), while PON activity 
was decreased significantally in patient with beta thalassemia compared to controls $(60.7 \pm 2.51) \quad \mathrm{U} / \mathrm{L} \quad(99.8 \pm 2.78) \mathrm{U} / \mathrm{L}$ respectively.

Table 2: Mean Indices of peroxidative stress, antioxidant status and vitamin profile in $\beta$ - thalassemia patients and control subjects.

\begin{tabular}{|c|c|c|c|}
\hline Parameter & Patients(n=75) & Control(n=50) & P value \\
\hline CAT (U/L) & $10.5 \pm 1.95 \mathrm{U} / \mathrm{L}$ & $24.5 \pm 1.84$ & $<0.001$ \\
\hline MDA ( $\mu \mathrm{M})$ & $4.41 \pm 0.52 \mu \mathrm{M}$ & $1.22 \pm 0.45$ & $<0.001$ \\
\hline GSH ( $\mu \mathrm{M})$ & $5 . .3 \pm 1.22 \mu \mathrm{M}$ & $9.6 \pm 1.43$ & $<0.001$ \\
\hline Paraoxonase (U/L) & $60.7 \pm 2.51 \mathrm{U} / \mathrm{L}$ & $99.8 \pm 2.78$ & $<0.001$ \\
\hline Iron ( $\mu \mathrm{M})$ & $16.7 \pm 1.95 \mu \mathrm{M}$ & $9.75 \pm 2.11$ & $<0.001$ \\
\hline Ferritin ( ng/ml) & $1525 \pm 95.5$ & $95 \pm 13.8$ & $<0.0001$ \\
\hline $\begin{array}{c}\text { Vitamin E } \\
\text { (nmole/L) }\end{array}$ & $0.54 \pm 0.12$ & $1.89 \pm 0.16$ & $<0.05$ \\
\hline Vitamin C (ng/ml) & $4.85 \pm 0.92$ & $10.5 \pm 2.87$ & $<0.001$ \\
\hline Vitamin A ( $\mu \mathrm{M})$ & $0.64 \pm 0.11$ & $1.55 \pm 0.21$ & $<0.001$ \\
\hline Vitamin D (ng/ml) & $16 \pm 1.8$ & $34 \pm 2.2$ & $<0.001$ \\
\hline Isoprostane (pg/ml) & $270 \pm 19$ & $95 \pm 14$ & $<0.001$ \\
\hline $\begin{array}{c}\text { Apoprotein B-100 } \\
\text { (mg/dl) }\end{array}$ & $133.1 \pm 3.7$ & $114.2 \pm 4.5$ & $<0.001$ \\
\hline $\begin{array}{c}\text { Apoprotein AI (mg/ } \\
\text { dl) }\end{array}$ & $88.3 \pm 2.1$ & $77.7 \pm 2.3$ & $<0.001$ \\
\hline ApoB/ApoA ratio & $1.53 \pm 0.12$ & $1.52 \pm 0.13$ & $>0.05$ \\
\hline $\begin{array}{c}\text { Protein carbonyl } \\
\text { (mg/dl) }\end{array}$ & $22.4 \pm 1.8$ & $9.7 \pm 1.6$ & $<0.05$ \\
\hline $\begin{array}{c}\text { OH-gunanosine } \\
\text { (ng/ml) }\end{array}$ & $16.5 \pm 1.2$ & $6.6 \pm 2.1$ & $<0.001$ \\
\hline Cholesterol (mg/dl) & $144 \pm 5.3$ & $167 \pm 4.7$ & $<0.001$ \\
\hline $\begin{array}{c}\text { (mg/dl) } \\
\text { Triglycerides }\end{array}$ & $176 \pm 4.3$ & $150 \pm 3.9$ & $<0.05$ \\
\hline $\begin{array}{c}\text { (mg/dl)HDL } \\
\text { (mg/dl)LDL }\end{array}$ & $40 \pm 1.9$ & $45 \pm 2.7$ & $<0.05$ \\
\hline \begin{tabular}{c} 
(mg/dl)VLDL \\
\hline Acra
\end{tabular} & $35 \pm 2.2$ & $30 \pm 2.1$ & $<0.05$ \\
\hline
\end{tabular}

According to the results in the Table 2, the mean serum levels of Vitamin E, Vitamin C, vitamin A and vitamin D in all thalassemic patients samples were significantly lower than the control $(0.54 \pm 0.12$ vs. $1.89 \pm 0.16$ nmole $/ \mathrm{L}),(4.85 \pm 0.92$ vs. 10.5 $\pm 2.87 \mathrm{ng} / \mathrm{ml}),(0.64 \pm 0.11$ vs. $1.55 \pm 0.21 \mu \mathrm{M})$ and $(16 \pm 1.8$ vs. $34 \pm 2.2 \mathrm{ng} / \mathrm{ml}$ ) respectively. From Table 2 the thalassemic group had significantly higher levels of $\mathrm{OH}$ deoxyguanosine in comparison with healthy subjects, $(16.5 \pm 1.2) \mathrm{ng} / \mathrm{ml}$ vs. $(6.6 \pm 2.1)$ $\mathrm{ng} / \mathrm{ml}$ respectively. We used serum levels of the oxidized base, 8-hydroxy-2_-deoxyguanosine (8-OHdG), as our biomarker of oxidative damage. On the other hand total protein carbonyl levels in patients with $\beta$-Thalassemic major patients were found to be higher than those of the control group $(\mathrm{p}<0.05)$. The mean total protein carbonyl values were $22.4 \pm 1.8 \mathrm{mg} / \mathrm{dl}$ vs. $9.7 \pm 1.6$ $\mathrm{mg} / \mathrm{dl}$ in the group with $\beta$-Thalassemic major patients and the control respectively and the difference was significant at $\mathrm{P}<0.05$ value between those groups. As well to detect DNA damage in thalassemic status the F2-isoprostanes (F2-IsoPs) was measured in sera of those patients and results showed that the thalassemic group was significantly higher than that from healthy subjects, was observed $(270 \pm 19) \mathrm{pg} / \mathrm{ml}(95 \pm 14) \mathrm{pg} / \mathrm{ml}$ respectively.

The average total cholesterol values were measured in the group with $\beta$-Thalassemic major patients and the control group as $144 \pm 5.3 \mathrm{mg} / \mathrm{dl}, 167 \pm 4.7 \mathrm{mg} / \mathrm{dl}(\mathrm{p}<0.001)$, respectively; the average triglyceride values as $\mathrm{mg} / \mathrm{dl}, 176 \pm 4.3$ and $150 \pm 3.9 \mathrm{mg} /$ $\mathrm{dl}(\mathrm{p}<0.05)$, respectively. The HDL-cholesterol values as $40 \pm$ $1.9 \mathrm{mg} / \mathrm{dl}, 45 \pm 2.7 \mathrm{mg} / \mathrm{dl}(\mathrm{p}<0.05)$, respectively. Average LDL and VLDL values were found as $70 \pm 22 \mathrm{mg} / \mathrm{dl}, 92 \pm 2.9 \mathrm{mg} / \mathrm{dl}$ $(\mathrm{p}<0.05) ; 35 \pm 2.2 \mathrm{mg} / \mathrm{dl}, 30 \pm 2.1 \mathrm{mg} / \mathrm{dl}(\mathrm{p}<0.05)$, respectively. From Table 2, a significant decrease in serum lipoproteins, were observed in all $\beta$-Thalassemic patients when compared with controls. Figures $1 \& 2$ showed that the mean serum levels of Apo A1and Apo B-100 in all thalassemic patients samples were significantly lower than the control $(77.7 \pm 2.3$ vs. $88.3 \pm 2.1 \mathrm{mg} /$ dl) , (114.2 \pm 4.5 vs. $133.1 \pm 3.7 \mathrm{mg} / \mathrm{dl})$ respectively.

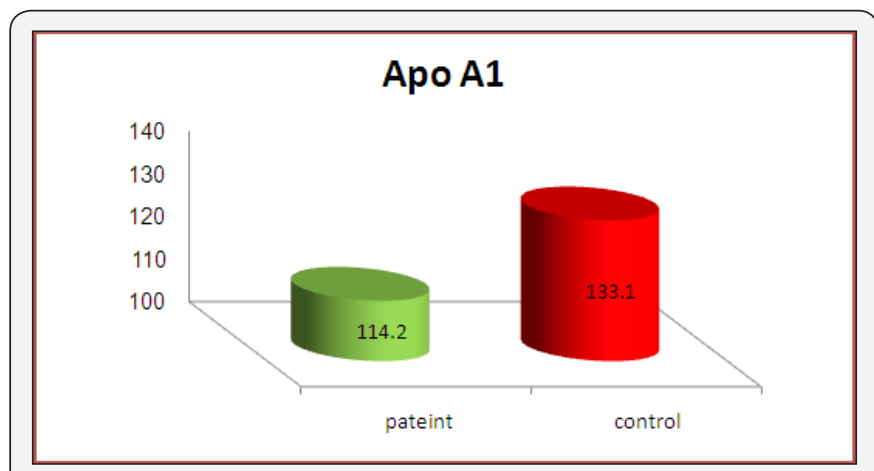

Figure 1: Mean serum Apo lipoprotein A1 levels of $\beta$ thalassemia major patients compared with controls.

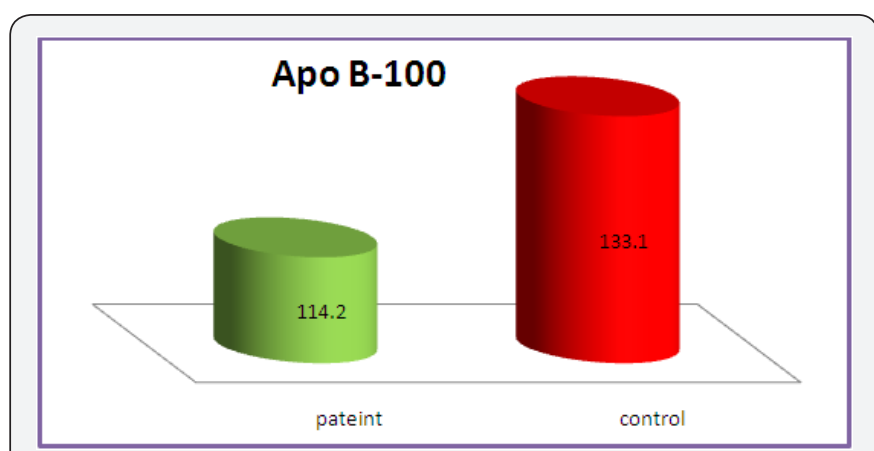

Figure 2 : Mean serum Apo lipoproteins B-100 levels of $\beta$ thalassemia major patients compared with controls.

\section{Discussion}

The most frequent hereditary blood disorder in the worldwide was $\beta$-thalassemia. Which encompass a wide variety of clinical phenotypes ranging in severity from clinically silent heterozygous $\beta$-thalassemia to severe transfusion dependent $\beta$-thalassemia major $[22,23]$. Oxidative stress in $\beta$-thalassemia major could explain many complications and may have therapeutic implications [24]. $\beta$-Thalassemia is a disease of red blood cells, clinical complications in several organs result from 
oxidative stress induced by iron overload in these patients and atherosclerosis-related vascular complications [23-25]. In beta thalassemia abnormally high levels of oxidative stress account for accelerated and increased destruction of erythrocytes [26]. Oxidative stress occurs when there is an imbalance between free radical production and antioxidant capacity. This may be due to increased free radical formation in the body and or loss of normal antioxidant defenses $[27,28]$ that can lead to a critical failure of biological functions and ultimately cell death [29,30]. $\beta$-Thalassemia patients had a similarly affected family member (90.0\%). while, El-Kamah [31] and his workers found that, Positive family history in $34.4 \%$ of thalassemia intermedia and thalassemia major.

Paraoxonase 1 is an antioxidant enzyme that inhibits the oxidative modifications of LDL as it can destroy active lipids in mildly oxidized LDL, Therefore the decrease in PON1 activity together with the decrease in total antioxidant capacity(TAC) leads to an increase in lipid peroxidation(malondialdehyde) and oxidative modification of lipoproteins that may lead to an increase in atherogenic risk $[23,32,33]$. This work revealed that Paraoxonase 1 and was significantly lower in $\beta$-Thalassemia patients than in the control group $(\mathrm{P}<0.01)$. The values of serum Paraoxonase 1 in $\beta$-Thalassemia major patients were two times respectively lower in $\beta$-thalassemia patients than in healthy control group. These findings denoted that these patients suffered from the effect of increased oxidative stress [3436]. Other studies reported that BTM patients had decreased paraoxonase 1 and arylesterase activities [37]. Noted decreased levels of serum PON1 activity and increased oxidative stress in $\beta$-thalassemia minor. On the other hand reduced glutathione (GSH), an antioxidant which prevents damage to the cellular components were measured in $\beta$ - thalassemia patients. Catalase (CAT), responsible for detoxification of hydrogen peroxide in the cells. Reduced glutathione level and catalase activity had highly significant decrease in $\beta$-thalassemia patients than in healthy children group. Level of GSH was three times lower in $\beta$-thalassemia patients than in healthy control group. These results were similar to those reported by others [38,39].

Reduced glutathione is a major intercellular reducing agent which is very sensitive to oxidative pressures and has several important functions such as: protection against oxidative stress and regulation of gene expression [39]. The results of the present work reported a deficiency in levels of catalase, which is 2.46 times lower in $\beta$-thalassemia major patients than in healthy control. These results were similar to those of [38,39], where low activity of catalase was detected; the decrease in activity was 2.75 times lower in beta-thalassemia patients than in the healthy control group. A possible explanation for lower catalase activity found in the more severe genotype of beta thalassemia is that the greater amount of hydrogen peroxide might produce direct toxic damage to catalase $[40,41]$. The concentration of this is considerably reduced in conditions of high oxidative stress [41-43].

\section{Conclusion}

The current study highlighted the state of vitamin profile found in beta thalassemia patients which revealed a significant decrease in vitamin A,C,D and E status. This study recommends the administration of antioxidants in beta thalassemia patients to ameliorate the symptoms and improve the quality of life in these patients.

\section{References}

1. Manca L, Masala B (2008) Disorders of the synthesis of human fetal hemoglobin. IUBMB Life 60(2): 94-111.

2. Clegg JB, Weatherall DJ (1999) Thalassemia and malaria: new insights into an old problem. Proc Assoc Am Phys 111(4): 278-282.

3. Sutcharitchan P, Saiki R, Huisman THJ, Kutlar A, McKie V, et al. (1995) Reverse dot-blot detection of the African-American $\beta$-thalassemia mutations. Blood 86(4): 1580-1585.

4. Hilliard LM, Berkow RL (1996) The thalassemia syndromes. Primary Care Update for OB/GYNS 3(5): 157-162.

5. Mehrvar A, Azarkeivan A, Faranoush M, Mehrvar, N Saberinedjad J, et al. (2008) Endocrinopathies in patients with Transfusion dependent $\beta$-thalassemia. Pediatr Hematol Oncol 25(3): 187-194.

6. Scott MD (2006) H2O2 injury in $\beta$ thalassemic erythrocytes: protective role of catalase and the prooxidants effects of GSH. Free Radic Biol Med 40(7): 1264-1272.

7. Meral A, Tuncel P, Sürmen-Gür E, Ozbek R, Oztürk E, et al. (2000) Lipid peroxidation and Antioxidant status in $\beta$-thalassemia. Pediatr Hematol Oncol 17(8): 687-693.

8. Advani R, Rubin E, Mohandas N, Schrier S (1992) Oxidative red blood cell membrane injury in the pathophysiology of severe mouse $\beta$-thalassemia. Blood 79(4): 1064-1067.

9. Olivieri O, De Franceschi L, Capellini MD, Girelli D, Corrocher R, Brugnara C (1994) Oxidative damage and erythrocyte membrane transport abnormalities in thalassemias. Blood 84(1): 315-320.

10. Grinberg LN, Rachmilewitz EA, Kitrossky N, Chevion M (1995) Hydroxyl radical generation in $\beta$-thalassemic red blood cells. Free Radic Biol Med 18(3): 611-615.

11. Schrier SL, Centis F, Verneris M, Ma L, Angelucci E (2003) The role of oxidant injury in the pathophysilology of human thalassemias Redox Rep 8(5): 241-245.

12. Draper HH, Hadley M (1990) MDA determination as a index of lipid peroxidation. Methods Enzymol 186: 421-430.

13. Beutler E, Duron O, Kelly BM (1963) Improved method for the determination of blood glutathione. Journal of Lab Clinical Medicine 61: p. 882-888.

14. Paglia D, Valentine W (1967) Studies on the quantitative and qualitative characterization of erythrocyte glutathione peroxidase. J Lab Clin Med 70(1): 158- 169.

15. Aebi H (1984) Catalase in Vitro. Methods Enzymol 105:121-126.

16. Menys VC, Liu Y, Durrington PN (2006) Semiautomated Method for Determination of Serum Paraoxonase Activity Using Paraoxonase Substrate. Clinic Chim 52(3): 453-457.

17. Thomas (1998) Clinical Laboratory Diagnostics (1 $1^{\text {st }}$ edn). pl69 Lothar Thomas ed. TH-Books Verlagsgesellschaft $\mathrm{mbH}$, Frankfurt/Main, Clinical chemistry Germany 45(4):586a-586.

18. Gorden M, Hanai R (1988) Determination of lipid profile using a new analytical method. J of clinical chemistry 7: 22-29. 
19. Schettler S, Taki M (1982) Detrmination of total glycerides by a modified spectrophotometric method. Clincal chem j 22: 677-690.

20. Theurl I (2009) Ferritin concentration in cellular monocyte extracts. Blood 107:4142-4148

21. Varley H (1967) Dipyridyl Method for Iron in Practical Clinical Biochemistry. (4th edn). p. 472.

22. Haghpanah S, Davani M, Samadi B, Ashrafi A, Karimi M (2010) Serum lipid profiles in patients with beta-thalassemia major and intermedia in southern Iran. J Res Med Sci 15(3): 150-154.

23. Labib HA, Etewa RL, Gaber OA, Atfy M, Mostafa TM, et al. (2011) Paraoxonase- 1 and oxidative status in common Mediterranean $\beta$-thalassaemia mutations trait, and their relations to atherosclerosis. J ClinPathol 64(5): 437-442.

24. Elsayh KI, Zahran AM, El Abaseri TB, Mohamed AO, El-Metwally TH (2013) Hypoxia Biomarkers, Oxidative Stress, and Circulating Microparticles in Pediatric Patients With Thalassemia in Upper Egypt. Clin Appl Thromb Hemost 20(5): 536-545.

25. Sonakul D, Suwanagool P, Sirivaidyapong P, Fucharoen S (1987) Distribution of pulmonary thromboembolic lesions in thalassemic patients. Birth Defects Orig Artic Ser 23(5): 375-384.

26. Muanprasat C, Wongborisuth C, Pathomthongtaweechai N, Satitsri S, Hongeng S (2013) Protection against oxidative stress in beta thalassemia hemoglobin E erythrocytes by inhibitors of glutathione efflux transporters. Academic J PLoS One 8(1): e55685.

27. Vassalle C, Botto N, Andreassi MG, Biagini B (2003) Evidence for enhanced 8-isoprostane plasma levels, as index of oxidative stress in vivo, in patients with coronary artery disease. Coron Artery Dis 14(3): 213-218.

28. Nabtchian F, Khaghani SH, Bacherian R, Miri R, Mahmoodi M (2004) The relationship between oxidative stress and the onset of the cornary disease. Medical journal of the Islamic Republic of Iran 18(2): 101-105.

29. Sayre M, Smith A, Perry G (2001) Chemistry and Biochemistry of Oxidative Stress in Neurodegenerative Disease. Current Med Chem 8(7): 721-738.

30. Nikolova G (2012) Oxidative stress and Parkinson disease. Anniversary edition
31. Trakia journal of sciences 10(1): 92-100.

32. El kamah G, hY Hosny, LA Sob HA (2009) Exploring Phenotypic Alterations in Response to High Hemoglobin F Level in Egyptian. Journal of applied Sciences Research 5(10): 1547-1551.

33. Mackness MI, Arrol S, Abbott CA, Durrington PN (1993) Protection of low-density lipoprotein against oxidative modification by high-density lipoprotein associated paraoxonase. Atherosclerosis 104(1-2): 129135.

34. Durrington PN, Mackness B, Mackness MI (2001) Paraoxonase and atherosclerosis. Arterioscler Thromb Vasc Biol 21(4): 473-480.

35. Livrea MA, Tesoriere L, Maggio A, DArpa D, Pintaudi AM, et al. (1998) Oxidative modification of low-density lipoprotein and athrogenetic risk in beta-thalassemia. Blood 88(9): 3936-3942.

36. Barrano B, Bertrand G, Isaja T, Curreri R, Musumeci S, et al. (2000) Plasma homocysteine is not involved in the thrombotic risk of b-thalassemia major patients. ActaHaematologica 104(2-3): 148-150.

37. Cakmak A, Soker M, Koc A, Erel O (2009) Paraoxonase and arylesterase activity with oxidative status in children with thalassemia major. J Pediatr Hematol Oncol 31(8): 583-587.

38. Selek S, Aslan M, Horoz M, Gur M, Erel O (2007) Oxidative status and serum Pon1 activity in beta-thalassemia minor. ClinBiochem J 40(5-6): 287-291.

39. Ruchaneekorn WK, Noppadol S, Praphaipit I, Ratiya C, Narumol P, et al. (2010) Improvement in oxidative stress and antioxidant parameters in ß-thalassemia / $\mathrm{Hb}$ E patients treated with curcuminoids. Clinical Biochemistry 43(4-5): 424-429.

40. Attia MMA, Sayed AM, Ibrahim FA, Mohammed AS, EL alfy MS (2011) Effects of antioxidant vitamins on the oxidation antioxidant status and liver function in homozygous ß-thalassemia .Romanian J Bio phy 21(2): 93-106.

41. Kirkman HN, Gaetani GF (1984) Catalase: Tetrameric enzyme with four tightly bound. Proc Natl Acad Sci 81(14): 4343-4347.

42. AL Mudalal SS, Musa RJ, AL Duliami N (2005) Antioxidant status in thalassaemic patients. Iraqi J Med Sci 4(1): 38-44.

43. Consolini R, Calleri A, Legitimo A (2001) Immunological evaluation of patients with beta-thalassemia majo. ActaHematol 105(1): 7-12.

\section{Your next submission with Juniper Publishers will reach you the below assets}

- Quality Editorial service

- Swift Peer Review

- Reprints availability

- E-prints Service

- Manuscript Podcast for convenient understanding

- Global attainment for your research

- Manuscript accessibility in different formats

( Pdf, E-pub, Full Text, Audio)

- Unceasing customer service

Track the below URL for one-step submission

https://juniperpublishers.com/online-submission.php 